\title{
The space group and crystal structure of trizinc diorthoborate
}

\author{
By Werner H. BaUR and EkKeHART TILlmanns
}

Department of Geological Sciences, University of Illinois, Chicago, Illinois

(Received 11 July 1969)

\section{Auszug}

Die Struktur des $\mathrm{Zn}_{3}\left(\mathrm{BO}_{3}\right)_{2}$ kristallisiert in der zentrosymmetrischen Raumgruppe $I 2 / c$, und nicht, wie Garcia-Blanco und Fayos (1968) annehmen, in Ic. Die neue Verfeinerung ergab $R=0,133$ für 787 beobachtete Strukturfaktoren, verglichen mit $R=0,132$, dem Wert, der von Garcia-Blanco und Fayos angegeben wurde. Die Bindungslängen und -winkel in der zentrosymmetrischen Struktur stimmen gut überein mit entsprechenden Werten in sorgfältig bestimmten anderen Strukturen, während die nichtzentrosymmetrische Struktur des $\mathrm{Zn}_{3}\left(\mathrm{BO}_{3}\right)_{2}$ eigentümliche Verzerrungen der Bindungslängen und -winkel aufweist.

\section{Abstract}

The structure of trizinc diorthoborate is shown to crystallize in the centrosymmetric space group $I 2 / c$, and not in $I c$ as assumed by GarCta-Branco and Fayos (1968) who determined the structure originally. The new refinement yielded an $R=0.133$ for $787 F_{\text {obs, }}$, as compared to $R=0.132$ achieved by the previous authors. The bond lengths and angles in the centrosymmetric structure agree well with values for comparable bonds in well determined structures, while the acentric structure exhibits some unusual distortions from the commonly accepted values.

\section{Introduction}

Garcia-Blanco and Fayos (1968) determined recently the crystal structure of $\mathrm{Zn}_{3}\left(\mathrm{BO}_{3}\right)_{2}$. The structure as described by them contains an unusual feature: the range of the values of bond lengths, which should be chemically equivalent, is large. The spread is 1.86 to $2.13 \AA$ for $\mathrm{Zn}-\mathrm{O}$, and 1.22 to $1.54 \AA$ for $\mathrm{B}-\mathrm{O}$ bonds and thus larger than for any known, well refined structure containing such bonds. Such a range can neither be explained by edge-sharing considerations (Pauling, 1960), since only one of the polyhedral edges is shared, nor can it be explained by the extended electrostatic valence rule 
(BAUR, 1961) because the charge of all the oxygen atoms is exactly balanced by the electrostatic bond strengths received from the cations.

\section{Refinement of the erystal structure}

Garcia-Blanco and Fayos claim that the refinement of their data to an $R$ of $13.2 \%$ (excluding the 15 largest $F_{\text {obs }}$ ) in space group Ic is final proof that the structure is acentric. The only indication they find for a higher symmetry is what they call a "pseudosymmetry in (010) projection with a false center in position $\frac{1}{4} \frac{1}{4}$ ". More careful inspection of the illustrations of the structure reveals, however, the presence of the following approximate symmetry elements: a two-fold axis in $0 y 0$, a two-fold screw axis in $\frac{1}{4} y \frac{1}{4}$ and centers of symmetry in $00 \frac{1}{4}$ and $\frac{1}{4} \frac{1}{4} 0$. That means that all symmetry elements of space group $I 2 / c$ are present if one allows shifts of a few hundredth of a cell edge in the positional parameters. Consequently we employed the $F_{\text {obs }}$ measured by Garcia-Blanco and Fayos in a refinement based on space group $I 2 / c$. As starting parameters we used the values for the unprimed atoms of their Table 3 ; however we shifted the origin of the unit cell by $3 / 4$ in the $c$ direction. All atoms are thus in the general eight-fold position of $I 2 / c$ with $\left(000 ; \frac{1}{2} \frac{1}{2} \frac{1}{2}\right) \pm\left(x y z ; x \bar{y} \frac{1}{2}+z\right)$. The unit-cell dimensions determined by Garcia-Blanco and Fayos $\left(a=23.406, b=5.048, c=8.381 \AA\right.$ and $\left.\beta=97.53^{\circ}\right)$ were used. All $B$ values were set initially at $1 \AA^{2}$. The scattering-factor curves for $\mathrm{B}^{+1}, \mathrm{O}^{-1}$ and $\mathrm{Zn}^{+2}$ from the International Tables, vol. III (1962) were employed in the structure-factor calculations. A Hughes-type

Table 1. Positional and thermal parameters of $\mathrm{Zn}_{3}\left(\mathrm{BO}_{3}\right)_{2}$

In parentheses are the estimated standard deviations in units of the last significant digits of the values

\begin{tabular}{l|c|c|c|c}
\hline \multicolumn{1}{c|}{ Atom } & $x$ & $y$ & $z$ & $B$ \\
\hline $\mathrm{Zn}(1)$ & $0.0495(1)$ & $0.8291(4)$ & $0.3746(2)$ & $0.61(7) \AA^{2}$ \\
$\mathrm{Zn}(2)$ & $0.1275(1)$ & $0.6841(4)$ & $0.7488(2)$ & $0.53(7)$ \\
$\mathrm{Zn}(3)$ & $0.2095(1)$ & $0.6921(4)$ & $0.4992(3)$ & $0.60(7)$ \\
$\mathrm{B}(1)$ & $0.0660(7)$ & $0.3213(31)$ & $0.5320(18)$ & $-0.3(2)$ \\
$\mathrm{B}(2)$ & $0.1870(7)$ & $0.1835(33)$ & $0.6683(19)$ & $-0.2(2)$ \\
$\mathrm{O}(1)$ & $0.0363(5)$ & $0.2018(24)$ & $0.6362(13)$ & $0.2(2)$ \\
$\mathrm{O}(2)$ & $0.0820(4)$ & $0.5885(23)$ & $0.5408(13)$ & $0.1(2)$ \\
$\mathrm{O}(3)$ & $0.0798(5)$ & $0.1874(24)$ & $0.4001(15)$ & $0.7(2)$ \\
$\mathrm{O}(4)$ & $0.1843(4)$ & $0.9117(25)$ & $0.6632(12)$ & $0.0(2)$ \\
$\mathrm{O}(5)$ & $0.2149(5)$ & $0.3132(21)$ & $0.5537(13)$ & $0.2(2)$ \\
$\mathrm{O}(6)$ & $0.1633(5)$ & $0.6783(21)$ & $0.2847(14)$ & $0.4(2)$
\end{tabular}


The space group and crystal structure of trizinc diorthoborate

Table 2. Observed and calculated structure factors

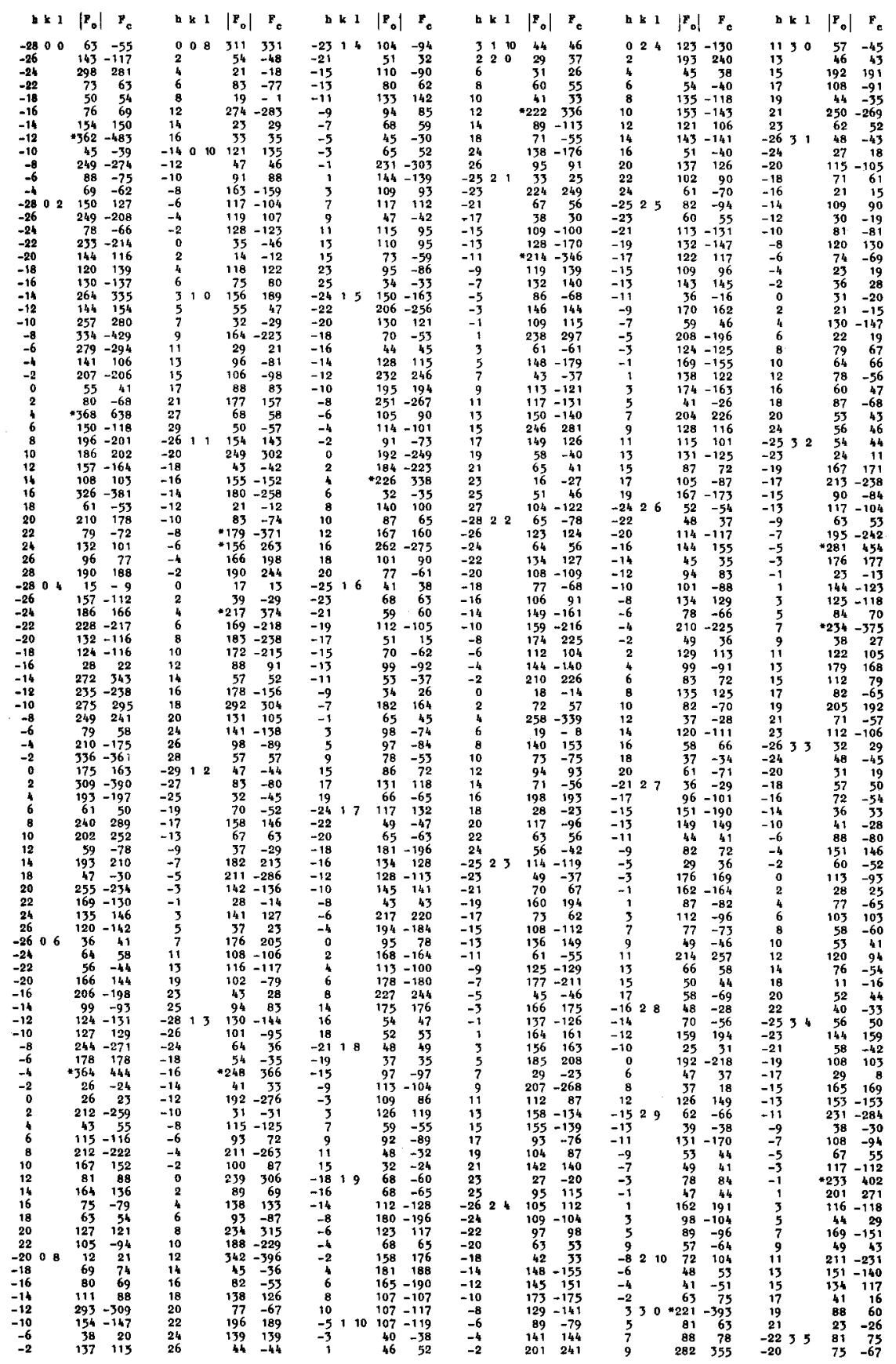




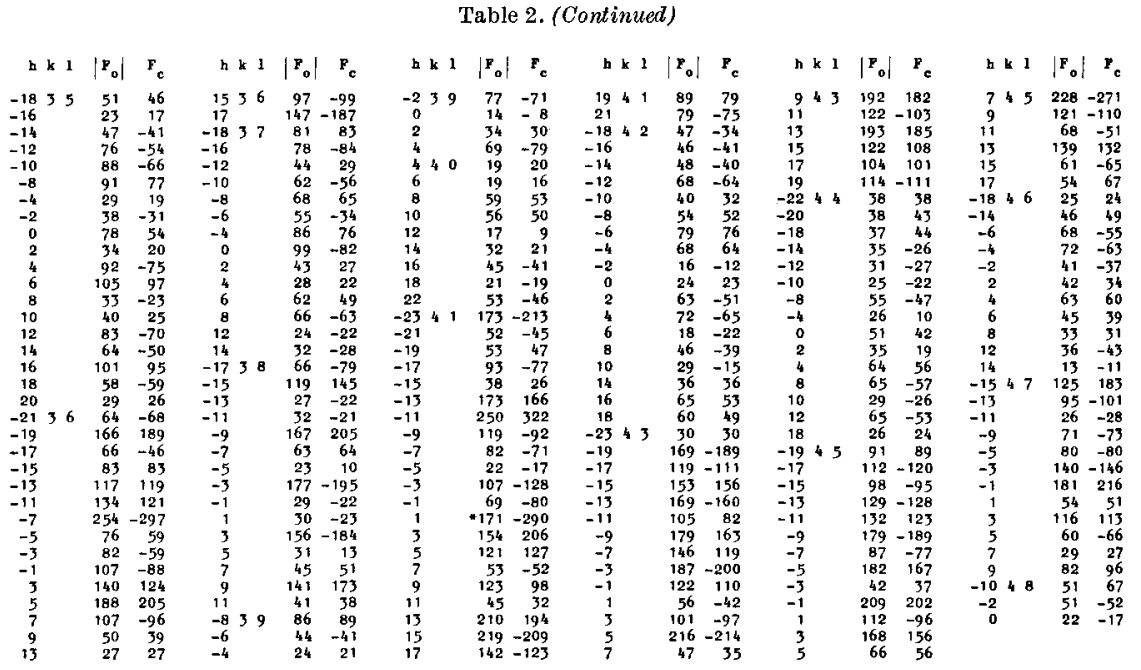

weighting scheme was applied in the refinement. The conventional $R$ value for the first structure-factor calculation was 0.24 . This dropped after four cycles of full-matrix least-squares refinement to 0.151 . If the 15 strongest reflections, which were given zero weight in the refinement, are left out, $R$ equals 0.133 . The final parameters are listed in Table 1. The $F_{\text {obs's }}$ given by Garcia-Blanco and Fayos

Table 3. Interatomic distances and angles with their estimated standard deviations

\begin{tabular}{|c|c|c|c|c|c|}
\hline Tetrahedron I & distance & $\begin{array}{l}\text { angle } \\
\text { around } \\
\mathrm{Zn}_{\mathrm{n}}\end{array}$ & Tetrahedron II & distance & $\begin{array}{l}\text { angle } \\
\text { around } \\
\mathrm{Zn}\end{array}$ \\
\hline $\mathrm{Zn}(1)-\mathrm{O}(2)$ & $1.93(1) \AA$ & & $\mathrm{Zn}(2)-\mathrm{O}(\mathbf{3})$ & $1.91(1) \AA$ & \\
\hline $\mathrm{Zn}(1)-\mathrm{O}(3)$ & $1.95(1)$ & & $\mathrm{Zn}(2)-\mathrm{O}(4)$ & $1.96(1)$ & \\
\hline $\mathrm{Zn}(1)-\mathrm{O}(1)$ & $1.99(1)$ & & $\mathrm{Zn}(2)-\mathrm{O}(2)$ & $1.98(1)$ & \\
\hline $\mathrm{Zn}(1)-\mathrm{O}(1)$ & $2.00(1)$ & & $\operatorname{Zn}(2)-O(6)$ & $2.02(1)$ & \\
\hline $\mathrm{O}(2)-\mathrm{O}(3)$ & $3.24(2)$ & $113.8^{\circ}(5)$ & $\mathrm{O}(3)-\mathrm{O}(4)$ & $3.38(2)$ & 121.8 \\
\hline $\mathrm{O}(2)-\mathrm{O}(1)$ & $3.58(2)$ & $132.2(5)$ & $\mathrm{O}(3)-\mathrm{O}(2)$ & $3.22(2)$ & 112.0 \\
\hline $\mathrm{O}(2)-\mathrm{O}(1)$ & $3.15(2)$ & 106.4 & $\mathrm{O}(3)-\mathrm{O}(6)$ & $3.38(2)$ & $118.4(5)$ \\
\hline$O(3)-O(1)$ & $3.03(2)$ & 101.0 & $\mathrm{O}(4)-\mathrm{O}(2)$ & $2.97(2)$ & 97.6 \\
\hline $\mathrm{O}(3)-\mathrm{O}(1)$ & $3.33(2)$ & $115.2(5)$ & $\mathrm{O}(4)-\mathrm{O}(6)$ & $3.21(2)$ & 107.3 (5) \\
\hline $\mathrm{O}(1)-\mathrm{O}(1)$ & $2.72(3)$ & $85.7 \quad(8)$ & $\mathrm{O}(2)-\mathrm{O}(6)$ & $2.93(2)$ & $94.3 \quad(5)$ \\
\hline \multicolumn{3}{|l|}{ averaged values } & \multicolumn{3}{|l|}{ averaged values } \\
\hline $\mathrm{Zn}(1)-\mathrm{O}$ & 1.97 & & $\mathrm{Zn}(2)-\mathrm{O}$ & 1.97 & \\
\hline $\mathrm{O}-\mathrm{O}$ & 3.18 & & $0 \quad-0$ & 3.18 & \\
\hline
\end{tabular}


Table 3. (Continued)

\begin{tabular}{|c|c|c|c|c|c|}
\hline Tetrahedron III & distance & $\begin{array}{l}\text { angle } \\
\text { around } \\
\mathrm{Zn}_{\mathrm{n}}\end{array}$ & Triangle I & distance & $\begin{array}{l}\text { angle } \\
\text { around } \\
\text { B }\end{array}$ \\
\hline $\begin{array}{r}\operatorname{Zn}(3)-O(4) \\
\operatorname{Zn}(3)-O(5) \\
\operatorname{Zn}(3)-O(6) \\
\operatorname{Zn}(3)-O(5) \\
O(4)-O(5) \\
O(4)-O(6) \\
O(4)-O(5) \\
O(5)-O(6) \\
O(5)-O(5) \\
O(5)-O(6)\end{array}$ & $\begin{array}{l}1.92(1) \AA \\
1.97(1) \\
1.97(1) \\
1.98(1) \\
3.27(2) \\
3.36(2) \\
3.20(2) \\
3.04(2) \\
3.20(3) \\
3.07(2)\end{array}$ & $\begin{array}{l}114.3^{\circ}(5) \\
119.3(4) \\
110.6(4) \\
100.9(5) \\
108.7(7) \\
101.9\end{array}$ & $\begin{array}{c}\mathrm{B}(1)-\mathrm{O}(1) \\
\mathrm{B}(1)-\mathrm{O}(2) \\
\mathrm{B}(1)-\mathrm{O}(3) \\
\mathrm{O}(1)-\mathrm{O}(3) \\
\mathrm{O}(1)-\mathrm{O}(2) \\
\mathrm{O}(3)-\mathrm{O}(2)\end{array}$ & $\begin{array}{l}1.33(2) \AA \\
1.40(2) \\
1.37(2) \\
2.34(2) \\
2.41(2) \\
2.34(2)\end{array}$ & $\begin{array}{l}120^{\circ}(1) \\
124(1) \\
116(1)\end{array}$ \\
\hline $\begin{array}{l}\text { averaged values } \\
\begin{array}{c}\mathrm{Zn}(3)-\mathrm{O} \\
\mathrm{O}-\mathrm{O}\end{array}\end{array}$ & \multirow{2}{*}{\multicolumn{2}{|c|}{$\begin{array}{l}1.96 \\
3.19\end{array}$}} & Triangle II & distance & $\begin{array}{l}\text { angle } \\
\text { around } \\
\text { B }\end{array}$ \\
\hline & & & $\begin{array}{c}\mathrm{B}(2)-\mathrm{O}(4) \\
\mathrm{B}(2)-\mathrm{O}(5) \\
\mathrm{B}(2)-\mathrm{O}(6) \\
\mathrm{O}(4)-\mathrm{O}(5) \\
\mathrm{O}(4)-\mathrm{O}(6) \\
\mathrm{O}(5)-\mathrm{O}(6)\end{array}$ & $\begin{array}{l}1.37(2) \AA \\
1.39(2) \\
1.37(2) \\
2.37(2) \\
2.39(2) \\
2.41(2)\end{array}$ & $\begin{array}{l}118^{\circ}(1) \\
121 \text { (1) } \\
121 \text { (1) }\end{array}$ \\
\hline
\end{tabular}

are compared with the calculated structure factors in Table 2 . The fact that the crystal structure could be refined in the centric space group (with half as many parameters as in the acentric one) to essentially the same $R$ value as in the acentric case shows that the centric space group is to be preferred. It is striking that all $B$ values are either small or negative (however not significantly negative if one considers the large estimated standard deviations); most likely this is correlated with the fact that the data were not corrected for absorption.

Further proof that the structure is more properly described in the centric space group comes from the fact that the bond lengths and angles (Table 3) now conform better with commonly accepted 
values. The reason that the bond-length values diverge so pronouncedly in Garcia-Buanco and Fayos acentric refinement is that the parameters of the atom pairs which should be related by a center of symmetry, but are not, are very highly correlated. Consequently they can be adjusted by large amounts in opposing, mutually compensating, directions.

We proved this point by refining by full-matrix least-squares methods Garcia-Blanco and Fayos's acentric model. It refined to an $R$ of 0.120 , but at the same time the correlations of most of the $x$ and $z$ parameters of the corresponding pairs of atoms became large. The shifts in parameters through four cycles of least-squares calculations remained large; on the average the shifts were bigger than one half the estimated standard deviations. And, what is even worse, many parameters tended to oscillate around a mean value. The bond distances were not improved by this further refinement in space group $I c$. The spread of $\mathrm{Zn}-\mathrm{O}$ bond-length values was 1.85 to $2.07 \AA$, while those of the B-O bond lengths was 1.18 to $1.55 \AA$. Some of the bond lengths which were the longest ones in Garcia-Blanco and Fayos's refinement of the structure became the shortest ones in our refinement in space group $I c$.

\section{Discussion of the crystal structure}

The topological connections of the coordination polyhedra remain unaltered by the refinement in the more highly symmetric space group. Therefore, Fig. 4, 5 and 6 in Garcia-Blanco and Fayos's paper are still a correct description of the crystal structure. However, individual bond lengths were changed by the refinement in extreme cases by $0.1 \AA$ or more.

The triangular coordinations around the boron atoms are now much more regular. Even the shortest bond length, $B(1)-O(1)$, is at best probably significantly shorter than the mean of the $\mathrm{B}-\mathrm{O}$ bond-lengths values in the two borate groups in $\mathrm{Zn}_{3}\left(\mathrm{BO}_{3}\right)_{2}$. The averaged value of all six B-O bond lengths is $1.37_{4} \AA$ which is remarkably close to the average value found in many well refined borates with boron in three-coordination. In $\mathrm{D}_{3} \mathrm{BO}_{3}$ (CRAVEN and SABINE, 1966) the average of six different $\mathrm{B}-\mathrm{O}$ bond lengths is $1.367 \pm 0.007 \AA$.

The $\mathrm{Zn}-\mathrm{O}$ distances in the tetrahedral coordination around the $\mathrm{Zn}$ atoms now range from 1.91 to $2.02 \AA$, while the mean $\mathrm{Zn}-\mathrm{O}$ bond length is $1.96_{4} \AA$. This average value agrees with other well determined bond distances: the average $\mathrm{Zn}-\mathrm{O}$ bond length is $1.972 \AA$ in hodg- 


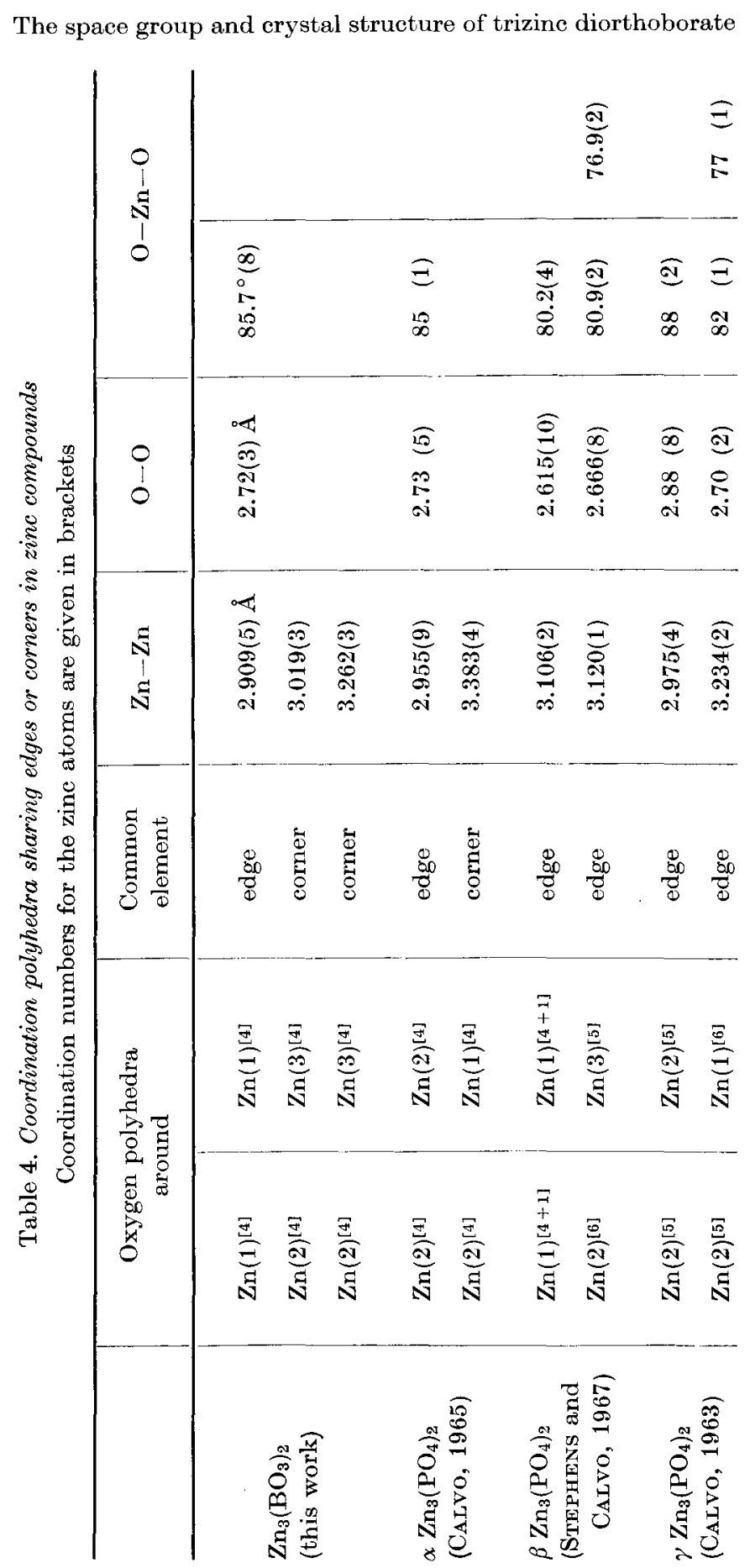


kinsonite (Rentzeperis, 1963) and $1.95 \AA$ in larsenite (PREwitT et al., 1967). The deviations of the individual distances from the mean are in some cases statistically significant. However, it is difficult to decide whether or not the accuracy of the structure determination is sufficient to accept these deviations as proved, because the intensity data have not been corrected for absorption.

A remarkable feature of the crystal structure is the common edge between the two $\mathrm{Zn}(\mathbf{1})$ tetrahedra connected by the two-fold axis. A shared edge between two coordination tetrahedra around multivalent cations usually should not occur according to Pauling's (1960) third rule for ionic crystals. The occurrence in $\mathrm{Zn}_{3}\left(\mathrm{BO}_{3}\right)_{2}$ adds another example to the short list of exceptions. Our search of the literature produced only one example of a crystal structure with a comparable arrangement involving $\mathrm{Zn}$ atoms, namely $\propto \mathrm{Zn}_{3}\left(\mathrm{PO}_{4}\right)_{2}$ (CALvo, 1965), where the geometry around the shared edge is virtually the same as in $\mathrm{Zn}_{3}\left(\mathrm{BO}_{3}\right)_{2}$. The geometry is already different in $\beta \mathrm{Zn}_{3}\left(\mathrm{PO}_{4}\right)_{2}$ (Stephens and Calvo, 1967) where the coordination around $\mathrm{Zn}(1)$ would be more properly described as $4+1$ since a fifth oxygen atom at a distance of $2.55 \AA$ from the $\mathrm{Zn}$ atom is present. These coordinations and a few other ones involving common edges between $\mathrm{Zn}$ coordination polyhedra are listed in Table 4. The geometry of the shared edges is somewhat similar in all cases irrespective of the coordination around the $\mathrm{Zn}$ atoms. For comparison we have listed

Table 5. Angles around the oxygen atoms

(with estimated standard deviations)

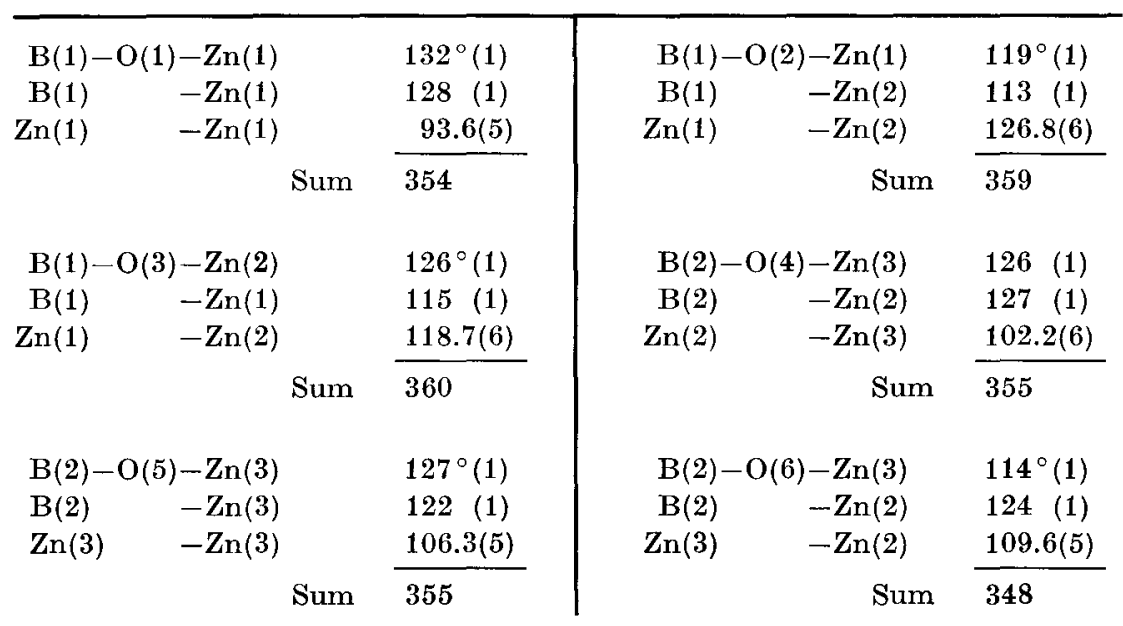


three of the $\mathrm{Zn}-\mathrm{Zn}$ distances between corner-sharing coordination tetrahedra. These $\mathrm{Zn}-\mathrm{Zn}$ distances are of similar length to those involving shared edges. This is made possible by the distortion around the common edge: the $\mathrm{O}-\mathrm{O}$ distances are relatively short, the angles $\mathrm{O}-\mathrm{Zn}-\mathrm{O}$ are small, and the distances $\mathrm{ZnO}-$ are usually longer than the average.

The sums of the bond angles around the oxygen atoms are all close to $360^{\circ}$ (Table 5). Therefore, the cation coordination around the oxygen atoms is, to a first approximation, planar.

\section{Conclusion}

Despite the fact that the erystal structure of $\mathrm{Zn}_{3}\left(\mathrm{BO}_{3}\right)_{2}$ can be refined to a lower $R$ value in space group $I c$, than it can be in $I 2 / c$, we prefer the latter one because in the centrosymmetric space group the resulting crystal structure is more reasonable on crystal-chemical grounds and because the refinement process is free from oscillations and correlations.

\section{References}

W. H. BAUR (1961), Verzerrte Koordinationspolyeder in heteropolaren Kristallstrukturen und die elektrostatische Valenzregel von Pauling. Naturwissenschaften $48,549-550$.

C. Calvo (1963), The erystal structure and luminescence of $\gamma$-zinc orthophosphate. J. Physies Chem. Solids 24, 141-149.

C. Calvo (1965), The crystal structure of $\propto \mathrm{Zn}_{3}\left(\mathrm{PO}_{4}\right)_{2}$. Can. J. Chem. 43, $436-445$.

B. M. Craven and T. M. Sabine (1966), A neutron diffraction study of orthoboric acid $\mathrm{D}_{3}{ }^{\mathrm{i1}} \mathrm{BO}_{3}$. Acta Crystallogr. 20, 214-219.

S. Garcia-Blanco and T. Fayos (1968), The erystal structure of zinc ortho. borate, $\mathrm{Zn}_{3}\left(\mathrm{BO}_{3}\right)_{2}$. Z. Kristallogr. 127, 145-159.

International tables for x-ray crystallography, Vol. III (1962), The Kynoch Press, Birmingham.

L. Pauling (1960), The nature of the chemical bond. Ithaca: Comell University Press.

C. T. Prewitt, E. Kirchner and A. Preisinger (1967), Crystal structure of larsenite $\mathrm{PbZnSiO}_{4}$. Z. Kristallogr. 124, 115-130.

P. J. ReNTzEPERIS (1963), The crystal structure of hodgkinsonite $\mathrm{Zn}_{2} \mathrm{Mn}$ $\left[(\mathrm{OH})_{2} \mid \mathrm{SiO}_{4}\right]$. Z. Kristallogr. 119, $117-138$.

J. S. Stephens and C. Calvo (1967), Crystal structure of $\beta-\mathrm{Zn}_{3}\left(\mathrm{PO}_{4}\right)_{2}$. Can. J. Chem. 45, 2303-2312. 